\title{
The Effect of Brand Personality and Social Media to Voting Behavior of Indonesia Presiden 2014
}

\author{
Linayati Lestari, Siti Sarawati Johar
}

\begin{abstract}
The purpose of this study was to analyze the effect of brand personality of Jokowi and social media to voting behaviour of Indonesia president 2014. The methods of this research conducted with quantitative methods. This research uses quantitative method. In this study also built on a review of the theory and results of previous studies. The population of this study are students faculty of social science and political science at Riau Kepulauan university force 2011-2015 users of social media twitter and facebook. Based on sample drawing technique Krejcie and Morgan obtained sample of 165 samples and the scale used is likert. Hypothesis testing is done by using multiple regression with the help of computer software SPSS 19.0. This study looks at the influence of five dimensions of Jokowi brand personality, sincerity, excitement, competence, sophistication, and ruggednes. Furthermore, this study also aims to identify the influence of social media twitter and facebook, and three dimensions of voting behavior that is sociological, psychological, and rational choice. The results of this study show the brand personality Jokowi in general categorized well with the dimension of brand personality the highest score is sincerity. Student voter behavior is generally categorized well with the rational choice dimension that has the highest score. Brand personality has a positive influence on voter behavior. Social media contribute significantly to voting behavior. In other words brand personality and social media together give influence to $P P$ equal to $23.1 \%$ while the rest $63.9 \%$ voting behavior influenced by other factor which not discussed in this research.
\end{abstract}

Index Terms: Brand Personality; Jokowi; President Election; Voting Behavior; Social Media.

\section{INTRODUCTION}

Brand Personality plays an important role in the glory of a brand. It causes customers to share the brand personality and develop a strong relationship with the brand (Doyle, 1990). A brand personality should be formed to be durable and consistent. In addition, brand personality must have different criteria from other brands in meeting consumer demands (Kumar et al., 2006). Implementation of direct democracy is also manifested in presidential and vice presidential elections

Revised Manuscript Received on September 22, 2019.

Linayati Lestari, Student Programme Doctor of Philosophy in Science Faculty Sains, Technology and Human Development University Tun Hussein Onn Malaysia (UTHM), Parit Raja Batu Pahat Johor, Malaysia and Lecturer in Government Science, Faculty of Social and Political Sciences, University of Riau Kepulauan, Indonesia, linayatilestari@yahoo.com

Siti Sarawati Johar, Lecturer Programme Doctor of Philosophy in Science Faculty Sains, Technology and Human Development University Tun Hussein Onn Malaysia (UTHM), 86400 Parit Raja Batu Pahat Johor, Malaysia, ssarajoe@gmail.com
At 2014 presidential election, the participants are composed of presidential candidates and vice presidents who will compete for voters vote of Indonesian society. The two pairs of candidates are Prabowo-Hatta candidates and candidate Jokowi-Kalla. The following are two (2) presidential and vice presidential candidates of Prabowo-Hatta and Jokowi-Kalla along with their supporting parties on the following chart:

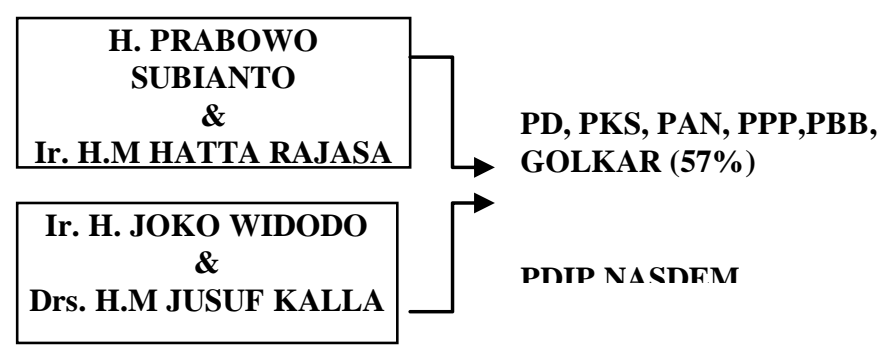

Fig. 1: Candidate of President 2014

Source: Processed results from the documentation study 2015

Based on figure mentioned above, each pair of candidates supported by a combination of political parties, the pair of sequences 1 (one) Prabowo-Hatta supported by Democratic Party (PD), Justice Party (PKS), Party Development Unity (PPP), Party of Work Party (Golkar), Amanat Nasional Party (PAN), and Party Stars Party (PBB). While the pair of 2 (two) Jokowi-Kalla supported by a coalition of Indonesian Democratic Party of Struggle (PDIP), the National Democratic Party (Nasdem) and the National Awakening Party (PKB).

Media in the concept of contemporary political communication is used to distinguish political products in political parties and candidates (McNair, 2011). This concept is different from the traditional political communication process, because in contemporary political communication there is a communication process with information exchange system, ideology, value system, norm and culture in open society (Firmanzah, 2008). Post-reform era, with the political democratization of the openness of opinion along with free, transparent and open political competition, is a new trend that is almost certainly its presence in the world of political communication (Firmanzah, 2008). The relationship between social media and the behavior of a lottery according to the

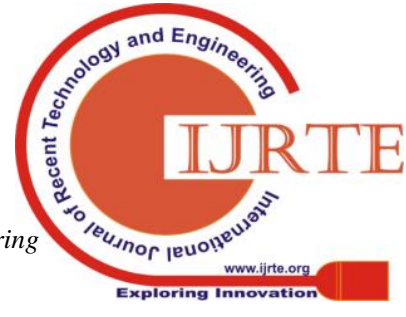


authors is that in the era of the Internet age like today, the figure of novice voters (students) is a layer of Indonesian society most in touch with communication technology and Internet based information.

Why do investigators choose Joko Widodo character who is often called Jokowi? This is because the character Jokowi known to many people and may be said to be on the rise. Not only that, Jokowi has some uniqueness. The uniqueness is not only on the style berpakainnya, his leadership style, but also the style of speech. Jokowi speech style is very thick with the local language, the Java language. Jokowi also has a special vocabulary or called by the term that I rapopo. Jokowi is also an ordinary human being. Of course Jokowi also has shortcomings or weaknesses in the aspect kebahasaannya.

The study's facts show that Joko Widodo-Jusuf Kalla's elektabilitas (Jokowi-JK) is higher than Prabowo Subianto-Hatta Rajasa. Seven of the nine study institutions concluded Jokowi-JK would be the winner of the presidential election on July 9th. Only two investigating agencies took prabowo-Hatta. The seven reviewing agencies that favor Jokowi-JK are Populi Center, Soegeng Sarjadi School of Government, Alvara Research, Cyrus Network, Survey Circle Indonesia (LSI), Pol-Tracking, and Indo Barometer. The one who favored Prabowo-Hatta was "only" the National Litigation Institute (LSN) and the United Data Center (GDP).

\section{A. Objective Research}

The objective of this study is the specific objective of why this study is to be carried out and the overall journey in this study is solely based on and attributed to these specific objectives. In this study, I will examine how the impression of the influence of brand personality and social media on the voters behavior of gamblers on the 2014 general election, the following are among the objectives of this study :

1. To examine Jokowi brand personality's significant impression on voter behavior.

2. To examine the significant influence of Jokowi's brand personality on social media.

3. To examine the significant influence of social media on voter behavior.

4. To determine the significant influence of social media as a moderating variable on the relation between Jokowi's brand personality and voter behavior.

\section{THEORITICAL REVIEW}

\section{A. Brand Personality}

Brand personality refers to the purpose of communication with respect to attributes inherent in a product as well as a perceptual profile received by consumers regarding a specific brand (James F. Engel, 1994). Consumers can give their perceptions of the brand's own personality, if the brand is in the process of brand communication and its products, or simply interpreted as a consumer's perception of a brand. Meanwhile, Aaker's brand personality is defined as a set of human characteristics associated with the brand. For example, characteristics such as gender, socioeconomic class, human personality traits such as highly sentimental or attentive (warmth).

Brand personality is the element that makes the brand come alive by giving human characteristics that make it more accessible and touchable. The main reason why customers imagine every brand has a personality is as part of the process of building and demonstrating their self-concept, whether it is the actual concept of their current self, as well as the ideal concept for themselves later. The concept of self is defined as the overall feeling and assumption of an individual when viewing themselves as an object.mFor example is Mercedes has a giving personality sophistication and exciting, while Nike has a rugged personality, and the personality of IBM is known as one of the most competent. Brand personality is one of the important factors forming a brand image and belonging to an attribute that is not related to the product. Where the characteristics of this type of attribute is not directly affect the product performance, but greatly affect the purchasing process for consumers (Kevin L. Keller, 1998). Based on its function that can be one of the amplifying factors for consumers in deciding the purchase, then brand personality is an important factor to be utilized by the company to get more attention and loyalty from consumers.

Another brand personality definition is according to Azoulay and Kapferer. According to them, brand personality is a set of human personality traits that can be applied to the brand and also relevant to the brand (A. Azoulay and J. Kapfefer, 2007). This notion seeks to straighten Aaker's research on the concept of brand personality, especially since Aaker's research is thought to be highly sensitive to intercultural differences, and focuses on the major issues in describing the properties of brand interconnection with humans (consumers), focusing only on the nature of reactions positive. In other words, Aaker's concept only focuses on the positive features of the brand personality traits that appeal to marketers, and put aside the negative attributes associated with the brand given by consumers. Azoulay and Kapferer also say that Aaker's brand personality definition includes unrelated aspects of brand identity, measuring the dimensions of product performance, and some things that seem less rooted in the definition of the term 'personality'. The exposure of the 'competence', 'feminine', and 'upper-class' indicators illustrates the intellectual, gender and social class.

\section{B. Social Media}

Social media is an online medium, with its users easily participating, sharing and creating content including blogs, social networks, wikis, forums and virtual worlds. Blogs, social networks and Wikis are the most common form of social media used by people around the world. According to Antony Mayfield of iCrossing, social media is about becoming a human being. Ordinary people who share ideas, collaborate and collaborate to create creations, think, argue, find people who can be good friends, find a partner and build a community. In 
essence, using social media makes us as ourselves. In addition to the speed of information that can be accessed in seconds, being yourself in social media is the reason why social media is growing rapidly. No exception, a desire for self-actualization and the need to create personal branding.

New web technologies make it easy for everyone to create and most importantly disseminate their own content. Posts on Blogs, tweets, or videos on YouTube can be reproduced and viewed by millions of people for free. Advertisers do not have to pay a lot of money to publishers or distributors to place their ads. Now advertisers can create their own content that is interesting and seen by many people (Zarrella, 2010: 2). According to Andreas Kaplan and Michael Haenlein defining social media as a group of internet-based applications built on the foundation of Web 2.0 ideology and technology, and enabling the creation and exchange of user-generated content. Web 2.0 became the basic platform of social media. Social media comes in many different forms, including social networks, internet forums, weblogs, social blogs, micro blogging, wikis, podcasts, rajahs, videos, ratings and social bookmarking (Kaplan and Haenlein, 2010; Weber, 2009).

Karjaluoto (2008: 2) reveals that the term social media mengRajahkan a media so that users can easily participate and contribute in the media. A common characteristic of every social media is the openness of dialogue between users. Social media can be changed by time and rearranged by the creator, or within certain sites, can be changed by a community. In addition social media also provides and forms a new way of communicating. As is known, before the emergence and popularity of social media, most people communicate by way of sms or phone calls via mobile phones. But now with social media, people tend to communicate through chat services or messaging through services available on social media.

\section{Voting Behavior}

Voting behavior is the behavior of a person in determining the choice that feels most liked or most suitable. In general the theory of choosing behavior is categorized into two camps namely; The Colombian School and the Michigan School within Fadillah. The Colombian school emphasizes sociological factors in shaping people's behavior in choosing elections. This model sees the community as a group entity that is vertical from the bottom to the top. Adherents of this approach believe that societies are structured by basic social norms based on sociological groupings such as religion, class (social status), occupation, age, gender are considered to have a decisive role in shaping voting behavior. Therefore, the choice preference for a political party is a product of the social characteristics of the individual concerned (Gaffar, 1992).

\section{METHODOLOGY/MATERIALS}

\section{A. The Research Design}

Testing requirements analysis in this study using statistical tests with path analysis techniques, thus the next step is a normality test that is useful to determine the data that has been collected normal distribution or not and linearity test aims to determine whether two variables have a relationship linear or not significantly. Test requirements are used to draw a conclusion from the results of research in the field consisting of several variables, including the variables Brand Personality, Social Media and Voter Behavior.

\section{B. Population and Sample}

Sample samples are reserved to follow Sample Determination Schedule (Krejcie and Morgan, 1970). The possibility of corrective sampling is $5 \%$ because the sample size formula by Krejcie and Morgan (1970) is awakened using a $95 \%$ confidence interval by 0.05 . After getting the names of the subjects in the population, the subject names have been randomly compiled. For selection of study respondents, a selection process has been carried out with the following formula: $290 / 165=1.75757576$. The number $n=$ 1.75757576 needs to be rounded to the nearest two digits. The $n=2$ numbers termed are named as duplicates. Saving respondents were selected as inventory if the actual number of respondents did not return home question, did not cooperate but may have been outside the region during the period of study. So the investigator has been overwhelming with the addition of 175 questions about the probing to ramp up as many as 300 respondents ie 169 people are the respondents of origin and their baskets is to take the possibility of the existence of a question that is not returned.

\section{Data Collecting Methods}

The data collecting that di in this research is field research that use observation and questionnaire which had prepared before.

\section{Data Analysis Method}

The method that is used in data analysis of this research is multipleregression analysis. Regression analysis used to find out how big that the independent variable impact to dependence variable. Because the method requires the scale measurement of the data at least is the interval data, leter before do the analysis the linear regression analysis requires to do by improve the ordinal scale to the interval scale. The data processing conducted by aid of the SPSS 19.0 program.

Table 1 : Instrument of Brand Personality, Social Media, and Voting Behavior

\begin{tabular}{|c|c|c|c|}
\hline Variable & Instrument & Subscale & Items \\
\hline \multirow{3}{*}{$\begin{array}{l}\text { Brand } \\
\text { Personality }\end{array}$} & Sincerity & $\begin{array}{l}\text { Down to earth, family } \\
\text { oriented, honest, sincere, } \\
\text { real, wholesome, } \\
\text { cheerfull, friendly }\end{array}$ & 8 \\
\hline & Excitement & $\begin{array}{l}\text { Daring, trendy, spirited, } \\
\text { young, unique, up to } \\
\text { date, independent }\end{array}$ & 7 \\
\hline & Competence & $\begin{array}{l}\text { Reliable, hard working, } \\
\text { intelligent, succesfull, } \\
\text { leader, confident }\end{array}$ & 6 \\
\hline
\end{tabular}




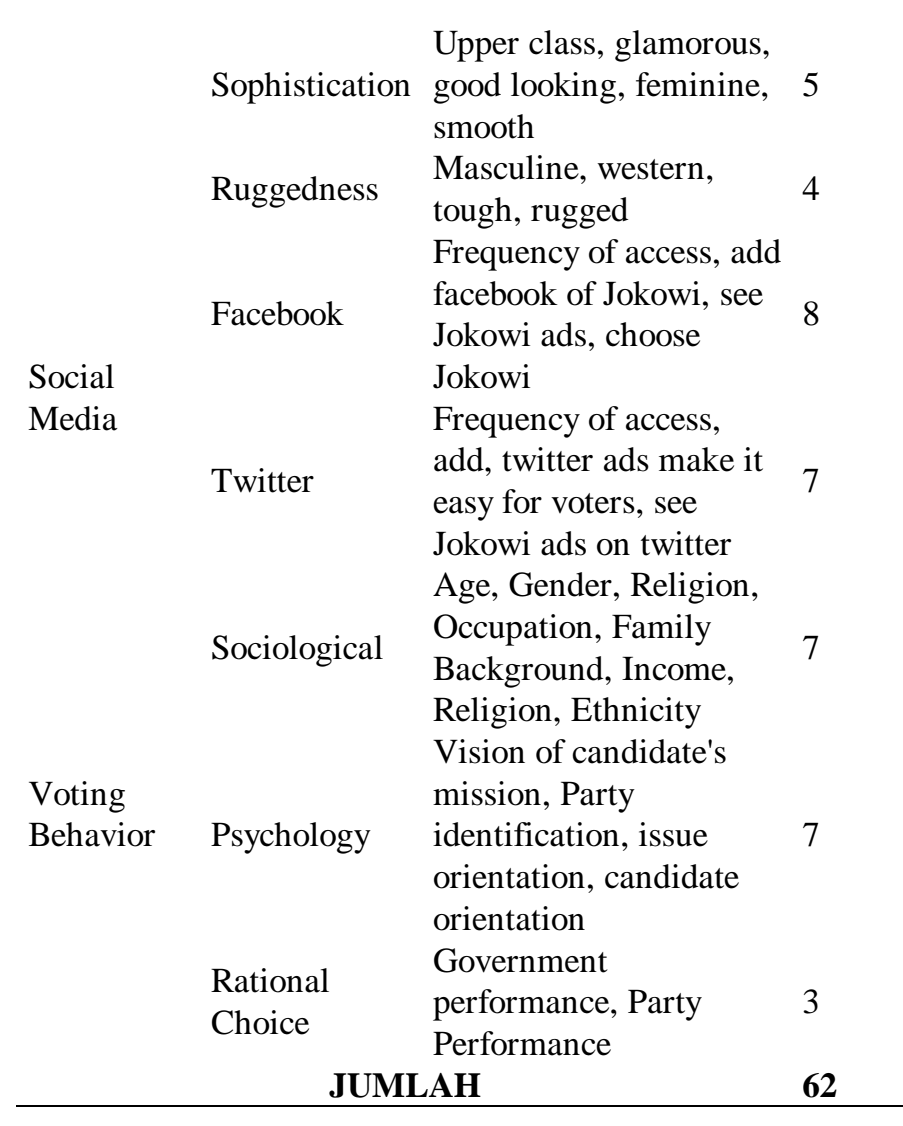

\section{RESULTS AND FINDINGS}

Table 2: Demographics of respondents

\begin{tabular}{|c|c|c|c|}
\hline & Item & Frekuensi & $\%$ \\
\hline \multirow{3}{*}{ Gender } & Man & 79 & 46.7 \\
\hline & Women & 90 & 53.3 \\
\hline & $17-24$ & 145 & 85.8 \\
\hline \multirow{3}{*}{ Age } & $25-31$ & 18 & 10.7 \\
\hline & $32-40$ & 4 & 2.4 \\
\hline & $>40$ & 2 & 1.2 \\
\hline \multirow{2}{*}{ Marital Status } & Single & 152 & 89.9 \\
\hline & Married & 17 & 10.1 \\
\hline \multirow[t]{11}{*}{ Work } & Entrepreneur & 29 & 17.2 \\
\hline & TNI / Polri & 0 & 0 \\
\hline & Royal Hand & 4 & 2.4 \\
\hline & Farmers & 1 & 0.6 \\
\hline & Merchants & 0 & 0 \\
\hline & $\begin{array}{l}\text { Teachers / } \\
\text { Lecturers }\end{array}$ & 9 & 5.3 \\
\hline & Private Section & 24 & 14.2 \\
\hline & Does not work & 65 & 35.8 \\
\hline & Etc & 37 & 21.9 \\
\hline & Not yet working & 79 & 46.7 \\
\hline & Below 1 Million & 6 & 3.6 \\
\hline \multirow[t]{3}{*}{ Income } & $\begin{array}{l}\text { Between 1-3 } \\
\text { Million }\end{array}$ & 61 & 36.1 \\
\hline & $\begin{array}{l}\text { Between 3-5 } \\
\text { Million }\end{array}$ & 19 & 11.2 \\
\hline & Above 5 Million & 4 & 2.4 \\
\hline \multirow[t]{5}{*}{ Force } & 2011 & 6 & 3.6 \\
\hline & 2012 & 5 & 3.0 \\
\hline & 2013 & 20 & 11.8 \\
\hline & 2014 & 72 & 42.6 \\
\hline & 2015 & 44 & 26.0 \\
\hline
\end{tabular}

\begin{tabular}{l|lll} 
& Rel6 & 22 & 13.0 \\
Religion & Islam & 142 & 84 \\
Kristen & 22 & 13 \\
Protestan & & \\
Katholik & 4 & 2.4 \\
Hindu & 1 & 0.6 \\
Budha & 0 & 0 \\
Jawa & 36 & 21.3 \\
Melayu & 66 & 39.1 \\
Padang & 14 & 8.3 \\
Batak & 20 & 11.8 \\
Bali & 2 & 1.2 \\
Bugis & 6 & 3.6 \\
Manado & 1 & 0.6 \\
Sunda & 4 & 2.4 \\
Nias & 2 & 1.2 \\
Flores & 9 & 5.3 \\
Ambon & 2 & 1.2 \\
Palembang & 4 & 2.4 \\
Jambi & 1 & 0.6 \\
Buton & 2 & 1.2 \\
\hline
\end{tabular}

Utilization of brand concepts in political campaigns has become a real phenomenon to be implemented in order to answer the challenges that exist at this time. A brand approach that is a further form of political marketing should be seen as a two-step communication process that directly affects consumers but also indirectly through media mediation (O'Saughnessy, 2001: 1050). Brand concept is used to differentiate with political entities or existing political leaders.

Media has an important role in the process of democratization Because of its ability to convey information, educate, provide a platform for public political discourse, including facilitating the formation of public opinion, providing publicity to government and political institutions, as well as a channel for advocacy of political viewpoints. When this function is ideally met by the media, it will create a public space and ultimately democracy in the real sense (McNair, 1995: 18-20).

As a political brand, political leaders have an identity that must be conveyed to voters. Brand that is able to interact with voters is a brand that will succeed in the election (Nakanishi, 1974: 42). For that brand political leaders must get support from various parties, including the media in order to win votes.

Based on the description of data analysis results that have been processed with SPSS and testing the research hypothesis that has been done, it can be explained as follows: First, relationship brand personality of Jokowi to voting behavior after hypothesis testing individually gives result that there is significant relation to voting behavior variable. In this case the contribution of brand personality of Jokowi variable to productive behavior is 0.143 . In other words the value of $14.3 \%$ is due to changes in brand personality of Jokowi. The sum of $83.7 \%$ is a relation of other variables not studied in the structural model. 
Model Summary ${ }^{b}$

\begin{tabular}{llrrr}
\hline Model & R & $\begin{array}{c}\text { R } \\
\text { Square }\end{array}$ & $\begin{array}{c}\text { Adjusted R } \\
\text { Square }\end{array}$ & $\begin{array}{l}\text { Std. Error of } \\
\text { the Estimate }\end{array}$ \\
\hline 1 &, $379^{\mathrm{a}}$ &, 143 &, 138 & 7,817 \\
\hline
\end{tabular}

a. Predictors: (Constant), Brand Personality

b. Dependent Variable: Voting Behavior

Second, the relation between social media to voting behavior also gives positive result, meaning that there is significant correlation to voting behavior variable. The contribution of social media in this magnitude to productive behavior is 0.180 . In other words the value of voting behavior $18 \%$ is caused by changes in social media. The remaining $82 \%$ is the relationship of other variables.

Model Summary ${ }^{\text {b }}$

\begin{tabular}{llrrr}
\hline Model & R & R Square & $\begin{array}{c}\text { Adjusted R } \\
\text { Square }\end{array}$ & $\begin{array}{l}\text { Std. Error of } \\
\text { the Estimate }\end{array}$ \\
\hline 1 &, $424^{\mathrm{a}}$ &, 180 &, 175 & 7,651 \\
\hline
\end{tabular}

a. Predictors: (Constant), Social Media

b. Dependent Variable: Voting Behavior

Third, Jokowi relation brand personality and social media twitter and facebook after hypothesis testing simultaneously give result that there is positive relation to voting behavior. Coefficient of brand personalitu of Jokowi line (X1) and social media (X2) to voting behavior $(\mathrm{Y})$ equal to $\rho \mathrm{Yx} 1=$ 0.480 . With the coefficient of determination value of 0.231 and the residual coefficient of $\rho Y \varepsilon 1=\sqrt{ } 1-0.231=0.877$. Thus the sub-structure does not change. Where brand personality of Jokowi and social media contribute jointly to the voting behavior of $23,1 \%$.

In addition, other findings, if studied more deeply the amount of Social Media contribution contributes quite large when compared with Brand Personality. Therefore, with these findings, it is suggested that Social Media should receive considerable attention. Thus Voters Behavior can be well controlled. From the regression model shown the output as follows:

Coefficients $^{\mathrm{a}}$

\begin{tabular}{|c|c|c|c|c|c|c|}
\hline & & \multicolumn{2}{|c|}{$\begin{array}{c}\text { Unstandardized } \\
\text { Coefficients }\end{array}$} & $\begin{array}{c}\text { Standardized } \\
\text { Coefficients } \\
\end{array}$ & \multirow[b]{2}{*}{$\mathbf{t}$} & \multirow[b]{2}{*}{ Sig. } \\
\hline \multicolumn{2}{|c|}{ Model } & B & $\begin{array}{c}\text { Std. } \\
\text { Error }\end{array}$ & Beta & & \\
\hline 1 & $\begin{array}{l}\text { (Cons } \\
\operatorname{tant})\end{array}$ & 11,044 & 2,434 & & $\begin{array}{r}4,53 \\
8\end{array}$ & ,000 \\
\hline & $\mathrm{BP}$ & ,117 & 035 & ,248 & $\begin{array}{r}3,32 \\
2\end{array}$ & ,001 \\
\hline & SM & , 178 &, 041 &, 323 & $\begin{array}{r}4,33 \\
8\end{array}$ &, 000 \\
\hline
\end{tabular}

a. Dependent Variable: Voting Behavior

\section{CONCLUSION}

Voting behavior will increase if brand personality increases and social media also increases. From the regression equation above can be explained further as follows:

1. The value of the constant of the above equation is 11.044. The figure indicates the level of voting behavior when the brand personality and social media levels are ignored.

2. Brand personality variable has a coefficient value of 0.178 , the positive coefficient value shows a positive relationship brand personality to voting behavior, it means that if there is an increase in brand personality, voting behavior will increase by 0.178 pengalinya, assuming other independent variables are considered constant

3. The social media variable has a coefficient value of 0.178 , the positive coefficient value indicates a positive relationship of social media to voting behavior, it means that if there is an increase in social media, voting behavior will increase by 0.178 pengalinya, assuming other independent variables are considered constant.

\section{REFERENCES}

[1] A. Azoulay dan J. Kapferer (2007), "Do Brand Personality Really Measure Brand Personality?", Journal of Brand Management, (Vol. 2 No. 11, 2003), 143, www.jstor.org, diunduh pada tanggal 11 Desember 2007.

[2] Firmanzah. (2008). Marketing politik: antara pemahaman dan realitas. Jakarta: Yayasan Obor Indonesia.

[3] James F. Engel, Roger D. Blackwell, and Paul W. Miniard (1994), terj Budiyanto, Perilaku Konsumen, Jilid Pertama, Jakarta : Binarupa Aksara, 373.

[4] Kevin L. Keller. 1998. Strategic Brand Management: Building, Measuring, and Managing Brand Equity, New Jersey: Prentice Hall, 59.

[5] Khang, H., Ki, Eyun \& Ye, Lan. (2012, March). Social media research in advertising, aommunication, marketing, and public relations, 1997-2010. Retrived May 5, 2013, from http://jmq.sagepub.com/content/89/2/279.

[6] McNair, B. (2010). An introduction to political communication. Oxon, Canada: Routledge.

[7] O'Saughnessy, N. (2001). The Marketing of Political Marketing. European Journal of Marketing Vol 35, No. 9/10. Special Issue Summer 2001, pp. 1047-1057.

[8] Setiadi, Elly M. dan Usman Kolip. (2011). Pengantar Sosiologi Pemahaman, Fakta dan Gejala Permasalahan Sosial: Teori, Aplikasi dan Pemecahannya. Jakarta: Kencana.

[9] Zhang Mengxia (2007). Impact of Brand Personality on PALI: A Comparative Research Between Two Different Brands. International Management Review (Vol. 3 No. 3).

[10] Zeithaml, V. A., Berry, L. L. and Parasuraman, A. (1996b). The behavioral consequences of service quality. Journal of marketing, 60(2).

[11] Zhang, Y. (2015). The Impact of Brand Image on Consumer Behavior: A Literature Review. Open Journal of Business and Management, 3(01), 58 .

\section{AUTHOR PROFILE}

My name is Linayati Lestari, i am Student Programme Doctor of Philosophy in Science Faculty Sains, Technology and Human Development University Tun Hussein Onn Malaysia (UTHM), Parit Raja Batu Pahat Johor, Malaysia and Lecturer in Government Science, Faculty of Social and Political Sciences, University of Riau Kepulauan, Indonesia. My area of interest is social sciences.

My name is Siti Sarawati Johar, I am working as Lecturer Programme Doctor of Philosophy in Science Faculty Sains, Technology and Human Development University Tun Hussein Onn Malaysia (UTHM), 86400 Parit Raja Batu Pahat Johor, Malaysia and area of interest is social sciences. 